\title{
Does Optimization of Balance Sheet Indicators Can Have Impact on External Financiers?
}

\author{
JEVTIC Dalibor ${ }^{1}$, VESIC Tamara ${ }^{2}$ \\ ${ }^{1}$ Filinav doo, Belgrade, (SERBIA) \\ ${ }^{2}$ Faculty of Business Economy and Entrepreneurship, Belgrade, (SERBIA) \\ Emails:dalibor.jevtic@filinav.com, tamara.vesic@vspep.edu.rs
}

\begin{abstract}
In the matter of decision-making aspect by the banks in Serbia to evaluate each business model, and at the same time to meet client's requirements on the one hand and official standards on the other, is a topic that involves a large number of potential and current bank clients. Looking at the real demands of companies in Serbia for the approval of credit products, we can confirm that banks in Serbia want to aprove balances that are ideally calculated, which is why we have non-standardity in making decisions about lending to potential clients. The focus on the turnover size, the number of employees, the EBITDA and the equity of the company are the factors that lead to mistakes in both cases - approval and rejection of the clients. The aim of this document is to try to confirm, by analyzing specific examples, that it is necessary to go into the business of each potential client, instead of satisfying only the standard forms that the bank sets for the clients and thus influence the process of decision making in banks.
\end{abstract}

Keywords: credit, banks, business optimization, financial statements, indicators

JEL: M20

UDK: 005.332:005.591.1

339.727.22

\section{Introduction}

The financial system, in every country is regulated by various standards. International standards provide general frameworks beyond which the business of financial institutions is considered unregulated, while local standards [1] with respecting of international business frameworks, regulate the operation of financial institutions in more details [2].

In this article, we used specific companies with expectation to present possibilities to improve banks' credit decision-making process. The whole idea about this article come out from experience on local market and increasingly stringent rules, that have led to the positioning of new offers on financial market (such as factoring, investment and equity funds, microcredit institutions, various private investors - companies and individuals, etc.). Those new players are willing to take most of the risk, but also higher profit from the market [3].

Having in mind, all mentioned, we can expect consolidation of local banks sector. This can also create highly specialized banks [4]. On the other hand, all, we can easily call them noncredit types of financing, are not completely regulated (there is a question mark, is regulation of this type of market is difficult or there is no interest to be regulated?). That will leave door open for potential rapid enrichment, in the frame of existing regulations [5]. 
The research has five chapters. Introduction covers subject and aim of the research. Second chapter is for literature review and the third chapter covers methodology. The fourth chapter is for research results and conclusion is the last chapter of this article.

\section{Literature Review}

In order to better understand successfulness of one or any business, banking sector experts, mathematicians and economists have developed and created a number of indicators [6]. Every business, professionally managed, in every commercial and non-commercial sector, is based on the approved development strategy, presented in more details through plans and budgets on an annual basis [1]. Even with accepted international and local standards, bilanse sheets of the companies does not follow the expectation of external financiers' policy of risk and credit [7]. The possible development of approved budget can be in collision with competitiveness on the such market [8]. In order to be considered as low NPL bank, banks in Serbia will use the local, internally developed market benchmarks. Strong constraints connected with credit and risk policy on the banking sector in Serbia and their influence on financial markets of Serbia and in every other country, lead to the lot of rejected clients, which will use other types of financing (above mentioned). In last couple of years, alternative financial support institutions putting a pressure on those companies, while offering them unsecured and secured loans.

They are patient in waiting clients, with expectation of rejection notice from the client's banks [9]. The problem in the operations of banks occurs when they need to collect loans because, due to slower economic activity, clients are less and less able to fully and timely settle their obligations [10].

\section{Methodology}

The companies (10), in this article presented, are real, active companies that have been the subject of cooperation with the company Filinav doo (consulting company in financial sector). Sampled companies had requested a credit product with local banking institutions.

Names of the companies are created with 2 letters, where each letter represent:

- First letter - represent the revenue size - A to $\mathrm{J}$ (A is the smallest revenue, $\mathrm{J}$ is the biggest),

- Second letter - stands for company size - S - small up to EUR 1 Million (M) revenue, $\mathrm{M}$ - medium - up to EUR 30M, L - large over EUR 30M.

All companies are presented in Table 1.

Under each company name is the year of incorporation, and the type of business. Each of the companies applied to different bank, in parallel, and that is way we can conclud that results of this research is aplicable to all banks operating in Serbia. The facts for each companie, in the moment of aplication, is that they: (a) did not have any material overdues according to the credit bureau (those who did, it was stated), (b) that the management is experienced in such business, (c) that the ownership structure is not reputationally relevant for the bank.

Those facts are important, as a "soft facts" from the decision maker point of view, since, upon fulfillment of all the above conditions, the decision was made mostly based on the client's financial indicators. The years of financial data presented, are taken as: first year presents year before application, second in the moment of loan approval/rejection, third data after loan approval.

The following table presents the crucial, official, on the 31.12. of presented year, finance date for each company individually.

Table 1. Crucial finance data of analysed companies 
Faculty of Business Economics and Entrepreneurship

International Review (2019 No. 3-4)

\begin{tabular}{|c|c|c|c|c|c|c|c|c|c|c|}
\hline Company & Year & Equity & Loans & $\begin{array}{c}\text { EBITD } \\
\text { A }\end{array}$ & $\begin{array}{l}\text { Emp } \\
\text {. No. }\end{array}$ & WC & $\begin{array}{c}\text { WC } \\
\text { Rati } \\
\text { o }\end{array}$ & $\begin{array}{c}\% \\
\text { Equity }\end{array}$ & $\begin{array}{c}\text { DEBT/ } \\
\text { EBITD } \\
\text { A }\end{array}$ & $\begin{array}{c}\% \\
\text { Profit }\end{array}$ \\
\hline AS & $\begin{array}{r}201 \\
6\end{array}$ & 12 & 1 & 19 & 4 & 53 & 1.8 & $7.40 \%$ & 0.1 & $3.40 \%$ \\
\hline 2013 & $\begin{array}{r}201 \\
7\end{array}$ & 38 & 1 & 10 & 9 & 93 & 2.1 & $\begin{array}{c}16.10 \\
\%\end{array}$ & 0.1 & $2.90 \%$ \\
\hline $\begin{array}{l}\text { metal } \\
\text { production }\end{array}$ & $\begin{array}{r}201 \\
8\end{array}$ & 36 & 115 & 51 & 16 & -35 & 0.9 & $\begin{array}{c}11.20 \\
\%\end{array}$ & 2.3 & $5.10 \%$ \\
\hline BS & $\begin{array}{r}201 \\
4\end{array}$ & 234 & 404 & 550 & 9 & 387 & 1.5 & $\begin{array}{c}18.90 \\
\%\end{array}$ & 0.7 & $1.40 \%$ \\
\hline 2006 & $\begin{array}{r}201 \\
6 \\
\end{array}$ & 200 & 451 & 44 & 11 & 227 & 1.2 & $\begin{array}{c}15.30 \\
\%\end{array}$ & 10.3 & $3.50 \%$ \\
\hline construction & $\begin{array}{r}201 \\
8 \\
\end{array}$ & 269 & 705 & 142 & 17 & 492 & 1.3 & $\begin{array}{c}12.20 \\
\%\end{array}$ & 5 & $3.50 \%$ \\
\hline CS & $\begin{array}{r}201 \\
4\end{array}$ & 1 & 68 & 0 & 0 & 0 & 1 & $1.40 \%$ & 0 & $0.00 \%$ \\
\hline 2008 & $\begin{array}{r}201 \\
6\end{array}$ & 17 & 43 & 20 & 9 & 16 & 1 & $1.60 \%$ & 2.2 & $3.00 \%$ \\
\hline $\begin{array}{l}\text { developmen } \\
\mathrm{t}\end{array}$ & $\begin{array}{r}201 \\
8 \\
\end{array}$ & 98 & 107 & 75 & 10 & 106 & 1 & $4.00 \%$ & 1.4 & $4.10 \%$ \\
\hline DS & $\begin{array}{r}201 \\
6\end{array}$ & 20 & 46 & 31 & 18 & -94 & 0.8 & $4.30 \%$ & 1.5 & $1.70 \%$ \\
\hline 2010 & $\begin{array}{r}201 \\
7 \\
\end{array}$ & 73 & 220 & 42 & 16 & -34 & 0.9 & $\begin{array}{c}15.70 \\
\%\end{array}$ & 5.2 & $3.00 \%$ \\
\hline wholesale & $\begin{array}{r}201 \\
8 \\
\end{array}$ & 73 & 189 & 781 & 17 & 49 & 1 & $5.80 \%$ & 0.2 & $0.10 \%$ \\
\hline EM & $\begin{array}{r}201 \\
6\end{array}$ & 16 & 0 & 343 & 5 & -215 & 0.9 & $0.90 \%$ & 0 & $0.40 \%$ \\
\hline 2014 & $\begin{array}{r}201 \\
7\end{array}$ & 29 & 0 & 287 & 10 & -626 & 0.8 & $0.80 \%$ & 0 & $0.50 \%$ \\
\hline $\begin{array}{l}\text { drugs } \\
\text { production }\end{array}$ & $\begin{array}{r}201 \\
8 \\
\end{array}$ & 43 & 0 & 99 & 19 & 938 & 1.4 & $1.00 \%$ & 0 & $0.60 \%$ \\
\hline FM & $\begin{array}{r}201 \\
4\end{array}$ & 174 & 2 & 134 & 43 & 171 & 1.9 & $\begin{array}{c}48.20 \\
\%\end{array}$ & 0 & $\begin{array}{r}18.90 \\
\%\end{array}$ \\
\hline 2012 & $\begin{array}{r}201 \\
6\end{array}$ & 222 & 212 & 68 & 366 & 338 & 1.7 & $\begin{array}{c}24.60 \\
\%\end{array}$ & 3.1 & $0.80 \%$ \\
\hline security & $\begin{array}{r}201 \\
8 \\
\end{array}$ & 299 & 158 & 212 & 495 & 154 & 1.2 & $\begin{array}{c}20.70 \\
\%\end{array}$ & 0.7 & $6.60 \%$ \\
\hline GM & $\begin{array}{r}201 \\
6 \\
\end{array}$ & 7 & 8 & 11 & 6 & 15 & 1.3 & $9.10 \%$ & 0.7 & $1.20 \%$ \\
\hline 2015 & $\begin{array}{r}201 \\
7\end{array}$ & 96 & 97 & 117 & 10 & 80 & 1.7 & $\begin{array}{c}27.10 \\
\%\end{array}$ & 0.8 & $3.10 \%$ \\
\hline recycling & $\begin{array}{r}201 \\
8\end{array}$ & 2,359 & 118 & 485 & 12 & 530 & 4 & $\begin{array}{c}84.20 \\
\%\end{array}$ & 0.2 & $2.60 \%$ \\
\hline HM & $\begin{array}{r}201 \\
4\end{array}$ & 48 & 0 & 47 & 30 & 357 & 1.9 & $5.80 \%$ & 0 & $3.30 \%$ \\
\hline 2014 & $\begin{array}{r}201 \\
6\end{array}$ & 203 & 63 & 93 & 16 & 73 & 1.1 & $\begin{array}{c}16.10 \\
\%\end{array}$ & 0.7 & $1.80 \%$ \\
\hline $\begin{array}{l}\text { agro } \\
\text { industry }\end{array}$ & $\begin{array}{r}201 \\
8 \\
\end{array}$ & 395 & 260 & 225 & 20 & 386 & 1.4 & $\begin{array}{c}23.10 \\
\%\end{array}$ & 1.2 & $3.20 \%$ \\
\hline IM & $\begin{array}{r}201 \\
2\end{array}$ & 1,577 & 5,056 & 1,663 & 128 & 3,605 & 2.5 & $\begin{array}{c}19.50 \\
\%\end{array}$ & 3 & $8.40 \%$ \\
\hline 2001 & $\begin{array}{r}201 \\
4\end{array}$ & 2,392 & 5,820 & 1,178 & 129 & 1,955 & 1.8 & $\begin{array}{c}26.00 \\
\%\end{array}$ & 4.9 & $4.10 \%$ \\
\hline
\end{tabular}




\begin{tabular}{|c|r|r|r|r|r|r|r|r|r|r|}
\hline wholesale & $\begin{array}{r}201 \\
8\end{array}$ & 4,540 & 5,548 & 1,574 & 119 & 1,210 & 1.3 & $\begin{array}{r}32.80 \\
\%\end{array}$ & 3.5 & $4.90 \%$ \\
\hline JL & 201 & $\begin{array}{r}24,02 \\
0\end{array}$ & 48,599 & 15,319 & 266 & 4,283 & 1.1 & $\begin{array}{r}21.80 \\
\%\end{array}$ & 3.2 & $7.70 \%$ \\
\hline 1989 & $\begin{array}{r}201 \\
3\end{array}$ & $\begin{array}{r}47,10 \\
0\end{array}$ & 46,554 & 21,767 & 304 & 718 & 1 & $\begin{array}{r}34.00 \\
\%\end{array}$ & 2.1 & $9.30 \%$ \\
\hline $\begin{array}{l}\text { cereal } \\
\text { processing }\end{array}$ & 201 & $\begin{array}{r}34,42 \\
7\end{array}$ & 83,640 & 6,009 & 252 & $-24,439$ & 0.8 & $\begin{array}{r}24.70 \\
\%\end{array}$ & 13.9 & $-1.10 \%$ \\
\hline & 201 & 3,759 & $\begin{array}{r}137,40 \\
7\end{array}$ & $-1,977$ & 252 & $\begin{array}{r}11,58 \\
8\end{array}$ & 1.1 & $2.30 \%$ & -69.5 & $-29.00 \%$ \\
\hline
\end{tabular}

Source: [11]

Authors 'calculations for indicators

\section{Results and Discussion}

AS - it is an 95\% exporter, with industry required international certificates implemented.

AS have long-term agreements for purpose-built production. AS profitability is not significant, but growing, as EBITDA. In 2019, AS request was a long-term loan, secured with a mortgage. The bank did not support AS, due to small equity, and with out satisfactory EBITDA. The only negative aspect conected with banks decision are in the fact that long term export contracts are not seen as good enough collateral, even they are couple of time higher than the required loan amount.

BS - with very long experience in the construction industry, and production cycle of construction of the facility, of minimum of 2 calendar years, was not supported by the banks, on adequate approach. As one of the problems was raised the account blockade by the tax administration by mistake in 2013. After couple of years on various courts, BS won the case. After hiring an advisor, banks were in favour of BS in 2018, and with mortgages exceeding the value of the loan, a bigger loan amount was granted, which covered the amount that tax administration collected from the BS account. In this case, banks were driven by the size of collateral, more then a business model itself.

CS - This companies focus is construciton of residential buildings, in form of partership in project. The company had used couple very small bank loans, and always with pledge. The request was a loan for more than 36 months, in amount of EUR 300k, with a 6-month grace period. CS has long term experiense in this area, and with a very long reference list. However, in despite of all the indicators, the bank sought a mortgage on an existing facility, and had no understanding whatsoever to go in deep analysis of CS business. Not so trained banks officers, for this area of business, are going more for easiest option for the bank - always use much collateral as you can.

DS - is a wholesaler in fashion business, and always in pursuit for a long-term WC financing. The significant increase in revenue in 2017 and 2018, due to business transfer entirely on official cash flow. Increasing lending policy of commercial banks since 2017 until beginning 2019, without any deeper analysis what is behind those officially better standing of the company, led to default. In 2019, after tax administration control, and owner's inability to settle all penalties, he decided to shut down the DS.

EM - has implemented all standards, domestic and international, for drugs and supplements production. With wide list of domestic and foreign buyers, owned equipment, but low equity ratio, applied for short term loan in 2017. Idea was to pledge equipment and biggest long-term contracts with buyers. EM was rejected. In 2018 EM continued positive trend in his business.

FM - could not get a loan without any pledge, before 2018 official data. Due to improved financial data, FM received long term, unsecured loan. Three months after loan disbursement, FM lost its largest customer. This led to decreasing its monthly turnover by $50 \%$ and reduced its number of employees by 300 . 
GM - with similar credit history, as FM, he could manage to receive five-times unsecured debt in 2017. Profitability was completely neglected and increase of equity was recalculated by recapitalization.

HM - after 2017, problems with business financing 2018, were far more less due to official financial reports. From 2018 HM received EUR 450k loans. As of March 11, 2019, CHM has been in a blockade and bankruptcy proceedings have been initiated against it.

IM - The business of this company has been almost perfect in all parameters throughout its business years. The reason why this company it was among the sampled companies is that until 2014, the loan was only apporoved with real estate as a collateral and for a period not exceeding 24 months. Despite the fact that the company has been in business for a long time and the ownership and management structure had a lot of experience in its business, the bank did not consider this company as a good enough and often placed unfavorable loans - a short repayment period and with high interest. After optimizing balance sheet positions and angaging a counsultant, the company received a slightly larger loan and refinanced all its loans on the long term - from 36-60 months with a mortgage. Additionaly to that situation, they repackaged all those loans in 2018 and 2019 mainly covered only with promissory notes.

$\mathbf{J L}$ - this is an example of how companies that are "to big to fail" are viewed in Serbia. A four-year operating period was deliberately stated, in contrast to others, to show the movement of loans and equity. By 2013, the company was supported by banks, based on ratios that were, on paper, perfect. In 2014, company refinanced $60 \%$ of it`s loans, in January by one bank. and already in February 2014, there was a problem of repayment, on the very first installment. The stand still was plased, for all liabilities that lasted until 2017, where we can see a negative EBITDA, and a significant decrease in capital, which in 2018 is further adjusted. Regardless of the distorted parameters of finance, this company is considered to be to big to fail, and therefore receives another loan in 2018, where compared to 2013, the debt increases 3 times, while in the same period the number of employees decreases by $17 \%$.

\section{Conclusion}

Hence banks are increasingly demanding, and clients simply cannot adjust itself to the regulatory requirements, nor should they, the role of the bank is less the business supporter, and more imposed controlling role.

The problem arises with banks in Serbia - while they want to approve balances that are perfect at the cross-section, (generally 31.12.), and they have no understanding for businesses that are seasonal or specific. The inability to secure funds from banks, directs some of the illegal money to end up in that particular industry. In developed financial systems, in a turbulent business environment, there are daily changes that force financial institutions to adapt quickly to the current situation [12]. The principle according to which banks in Serbia operate is an inherited concept of a foreign bank's located in far more developed countries, and procedures and process are not in total applicable on local market. This approach increasing the level of alternative financing, until the client's official financial parameters are not in the line with banks requirements.

\section{REFERENCES}

1. National Bank of Serbia. (2019). Decision on classification of balance sheet assets and off-balance sheet items of the bank. Downloaded from http://www.nbs.rs/internet/cirilica/20/index_kpb.html on 1st of September 2019.

2. Cade, E. (1997). Managing Banking Risks - 1st edition. Woodhead Publishing.

3. Anbila, S., Sarettob, A., Tookesc, H. (2019). How does hedge designation impact the market's perception of credit risk? Journal of Financial Stability, Vol. 41, pp. 25-42. 
4. Djulic, K., Barjaktarovic, L., Pindzo, R., Vejtrov, A. (2017) Analysis of the capital structure decisions: a survey on Serbian companies, Ekonomika preduzeca, No. 5-6, pp. 355-364.

5. Barjakarovic, L. (2015). Risk Management, Singidunum University, Belgrade.

6. Mladenovic, V., Hadzic, M. (2014). Monetary and foreign currency policy of the European central bank. Singidunum Journal of Applied Sciences, 11(1), pp: 16-24.

7. Arping, S. (2019). Competition and risk taking in banking: The charter value hypothesis revisited. Journal of Banking \& Finance, pp. in progress, doi: https://doi.org/10.1016/j.jbankfin.2019.105609

8. Nikodijevic, M. (2018). Budžetiranje zasnovano na performansama kao instrument efikasne alokacije resursa na nivou lokalnih samouprava Republike Srbije. Trendovi u poslovanju, Sves. 1, Br. 11, pp. 5159.

9. Beckmanna, K., Escobarib, D., Ngo., T. (2019). The real earnings management of cross-listing firms. Global Finance Journal, Vol. 41, pp. 128-145.

10. Vesic T., Gavrilovic M., Petronijevic J. (2019). The influence of liquidity and profitability on the banking sector performances - the example of Serbia. International Review 1(2), pp. 75-81.

11. Serbian Business Registers Agency. (2019). Financial reports of analysed companies. Downloaded from http://pretraga3.apr.gov.rs/pretraga ObveznikaFI on 27 th of August 2019.

12. Dimic, M., Barjaktarovic, L. (2017). Vlasnička transformacija bankarskog sektora u zemljama jugoistocne Evrope. Bankarstvo, Vol. 46 (1), pp. 84-103.

\section{Article history:}

- Received 10 November 2019

- Accepted 18 December 2019 